J. M. H.--viz. the employment by some finches of flowers in the formation of their nests (NATURE, vol. xvi. p. 83, and vol. xxxvi. pp. IOI-2) -it may be worth while to sub.nit a detailed consideration of the case.

The front of the house of a friend living at No 47 Highbury Hill is covered by an extensive growth of white jasmine which reaches beyond the first-floor windows. For several years house-sparrows have used the bushy branches of this shrub without causing special attention. This year, however, they have taken a new departure in nest-building. Not satisfied, apparently, with the hay, straw, and other ordinary materials of sparrow architecture, they have suddenly aspired to appropriating to their use the bright yellow flowers of laburnum, two trees of which are in full bloom a few yards from the first-floor windowsills below which they are carrying on their operations. Three nests were discovered twelve days ago, built close together in the jasmine, all of which had laburnum $\mathrm{fl}$ owers strewn upon the top of ordinary nests; one nest contained two young birds just hatched, and the other two had each a couple of eggs. As they rather disturbed the Iady occupant of the house, she had all three nests destroyed, the litter from them entirely filling a large foot-bath. But the three pairs of birds, as might be expected, only set to work rebuilding their nests in the same place, furnishing them with more laburnum than before. They were however again disturbed, and an ob tacle (which in a previous year had proved effectual in stopping the building in another part of the house front) was set in the place of the nests, but still they did not desist ; two pairs continued to add their materials on the top of it, with more laburnum than ever, replenishing the nest as constantly as it was removed, while the third pair rebuilt their nest under the sill of the next window, using laburnum also. Even entire sprays of the flowers were used, and the ground beneath the trees was so much strewn with fragments that my friend at first thought that boys had been pulling the trees. All the birds are now allowed to remain unmolested, and the yellow decoration is withered, without fresh being provided.

This unaccustomed action of the sparrows is apparently somewhat different from the operations described by your correspondent I. M. H., for the bright golden flowers enveloping the nests are so strangely conspicuous as to attract the attention of passers by, and therefore cannot answer the protective purpose evident both in the case of the goldfinches with forgetme-nots and of the sparrows that used Alyssum. The only explanation I can suggest is that the birds have elevated their esthetic taste to this "quite too too" extent of art cultus: It is highly interesting to note also that-in opposition to the notions of the obsolete school of naturalists, who believed only in blind instinct-the rage for collecting their favourite "yellow" is infectious with these little yearners for the intense, just as is the desire for "blue" that now and then breaks out (like a disease) amongst larger householders. The three pairs of birds seemed to vie with one another in their revelry of the chosen colour. It will be instructive to learn whether the fashion will last for many seasons: perhaps it will languish of satiety, and some other attraction of a less absorbing kind arise.

The fondness of birds (in this country at least), for the col our yellow is perhaps worth considering in this connexion. A large number of wild or cultivated plants might be enumerated that produce yellow flowers, which are either used as food or have their petals mauled by birds. There need be no doubt, I think, that the mutilation of such flowers is due to a playful fondness rather than to a dislike of the flowers. That birds evidently exercise the selective faculty in the choice of flower is well illustrated by the fact, twice observed by my brother that sparrows pull to pieces the yellow flowers only in mixed beds of pansies, and of crocuses, without injuring a single purple, mauve, or white flower of either kind. I have myself also witnessed the same selective operation perfo:med by a sparrow on variouts crocuses growing in pots upon my windowsill, and I find many correspondents gave similar testimony to this fact in a series of leiters which appeared in these pages in the year 1877 (vols. xvi. and xvii.). It may be questioned whether the education of their preference for the colour yellow is in any way connected with the fact that it is proper to the yolk of their eggs, and which they must be aware of ; but since all good eggs contain that colour, while probably some birds do not like it and greatly prefer other colours, this suggestion may be no more valid as a theory than would be the argumen that some people's taste for cl tret-colour is due to the anal ogous physiological accident of arterial coloration. The rich yellow colour, again, of the beaks, entire mouths, and "open sepulchres" of the newly-hatched nestlings affords their parents ample opportunities for the contemplation of colour, and there may be an unconscious mental absorption of the colour in consequence of this course of training. At any rate, canary yellow is very highly developed in many species of the Fringillide, and there is a strong tendency towards the development of the yellowish colour in the plumage of the males of several British finches, apparently through a greenish-brown tinge. It is also well developed amongst the weavers and the orioles, to which they are so nearly allied. That sparrows should thus use sprays of flowers is perhaps not so remarkable when we recall the close affinity they bear to Ploceus and other weaver-birds.

Doubtless the colour-sense in birds, as well as in insects, is a real factor in the evolution of the floral beauty that surrounds them, although the modus operandi is not always one that can be so readily traced.

55 Highbury Hill, London, June 9.

\section{Names for Electric Units of Self-Induction and Conductivity.}

A NAME seems to be wanted for the practical unit of self induction, viz, an ohm multiplied by a second; in other words, for a length approximately equal to an earth-quadrant. Profs. Ayrton and Perry call it a "secohm." Why not call it a "quad"? It would be a handy great length for many other purposes. For instance, the velocity of light in air would be 30 quads per second, in common glass 20 quads per second.

To avoid misunderstanding, it would have to be understood that the actual earth-quadrant passing through any given place is only approximately a quad, its real value having to be determined geodetically. A quad is to be understood as ten million metres precisely.

Another unit requiring a name is the unit of conductivity. Sir William Thomson has suggested the word "mho," but it has not been greedily assimilated. I make the small suggestion of omitting the $h$. True, the expressions $12 \mathrm{mo}$ and $16 \mathrm{mo}$ would at first excite only bookbinding ideas, but they would soon carry a fresh meaning to electricians. OLIVER J. LODGE.

June I3.

\section{Units of Weight, Mass, and Force.}

THE necessity for names for the units of velocity and acceleration is very clearly illustrated by a criticism of my "Dynamics for Beginners," which appears in the Practical Engineer of June 3. After objecting to the introduction of new names, and explaining that a velo stands for a foot per second, the writer proceeds :- "The second new name is 'celo,' and is meant for an acceleration of one foot per second, or unit accelera. tion; so that if a body is moving with a velocity which is being accelerated at the rate of one foot per second, it is said in the new language to possess one celo. In other words, a celo means an acceleration of one foot per second, or of one velo." The italics are mine. I cannot resist quoting also the following sentence, which occurs a little lower down in the same criticism - "We think there is something ridiculous about the adoption of these names, which, while possessing the very questionable advantage of shortening the language of the subject by some two or three words, serve to muddle the mind of the student, and to obscure the sense by wrapping it up in meaningless words."

Why is not the Practical Engineer consistent ? He ought to state that just as a celo is unnecessary, for he considers it the same as a velo, in like manner a velo is unnecessary, for by the same line of argument it must be the same as a foot. The fact is that the names velo and celo are not necessary for scientific men, although I expect they will be found to be convenient. It is, I believe, generally admitted that some such words are greatly needed by teachers; for it is the clear mental differentiation of the ideas expressed by velo and celo, or the want of it, which often marks the distinction between a sound physicist and a muddler.

Gonville and Caius College, June 4.

I AGREE with your correspondent, Mr. R. B. Hayward (NATURF, vol. xxxv. p. 604), in holding that names for the dynamical units are of less importance than a convenient nota- 